$0=$ initial condition

$A \quad=$ acetic acid

$L \quad=$ lactic acid

\section{Literature cited}

1) Audinos, R. and A. Nassr-Allah: J. Membrane Sci., 76, $147-156$ (1993)
2) Lee, K. and J. Hong: J. Membrane Sci., 75, 107-120 (1992)

3) Shah, P. R. and A. S. Kovval: Chem. Eng. J., 51, 1-6 (1993)

4) Weier, A. J. and B. A. Glatz: Biotechnol. Prog., 8, $479-$ 485 (1992)

5) Zhang, S. T. and H. Matsuoka: J. Ferment. Bioeng., 75, $276-282$ (1993)

\title{
Permeation Behavior of Organic Acids through a Membrane with Electrodialysis
}

\author{
Naoki Katayama, Susumu Nii, Katsuroku Takahashi, \\ Masamichi Kamihira and Hiroshi Takeuchi
}

Dept. of Chem. Eng., Nagoya Univ., Nagoya 464-01

\begin{abstract}
Key Words: Membrane Separation, Electrodialysis, Ion Exchange, Anion Exchange Membrane, Lactic Acid, Acetic Acid

For electrodialysis of lactic and acetic acids, the effect of $\mathrm{pH}$ on the permeation behavior was examined. A strong basic or perfluoro anion exchange membrane was used. Even when the organic acids were undissociated, permeation of these acids was observed and the addition of $\mathrm{HCl}$ promoted the permeation rate. The permselectivity of lactic acid over acetic acid was large at low $\mathrm{pH}$ and decreased as the dissociation of acetic acid proceeded at high $\mathrm{pH}$.
\end{abstract}

\section{TOA を担体とする乳化型液体膜によるクロムの抽出 一外部水相, 油相, 内部水相中のクロム含有率に及ぼす TOA 濃度の影響——}

\section{叶 偉清・原 新一・大平勇一 \\ 小幡英二・安藤公二}

\section{室蘭工業大学 応用化学科}

\begin{abstract}
前報4)では，市販の界面活性剂 Span 80, ポリアミン を用いてクロムイオンの濃縮回収過程における外部水相, 油相および内部水相三相中のクロムイオン濃度を実測し, 内部水相中のクロムイオン濃度は最大值に達した後比較 的急激に減少し続けるため, 高い内部水相濃度を得るに は適切な抽出時間の設定が重要であることを示した. ま
\end{abstract}

$\dagger 1994$ 年 10 月 28 日受理

†† 050 室蘭市水元町 $27-1$

第 21 巻 第 4 号 (1995)
た, 前報) と江口ら ${ }^{2)}$, 森ら ${ }^{3)}$ との濃縮回収結果の違いは, TOA 濃度の差異であると推論した。

本報は, Span 80 および 2 種のポリアミンについて, クロムイオンの濃縮回収過程における外部水相, 油相, 内部水相中のクロムイオン含有率の経時変化に及ぼす TOA 濃度の影響について実験的に検討し, クロムイオ ンの濃縮回収を実現するための TOA 濃度および抽出時 間を明らかにした。 


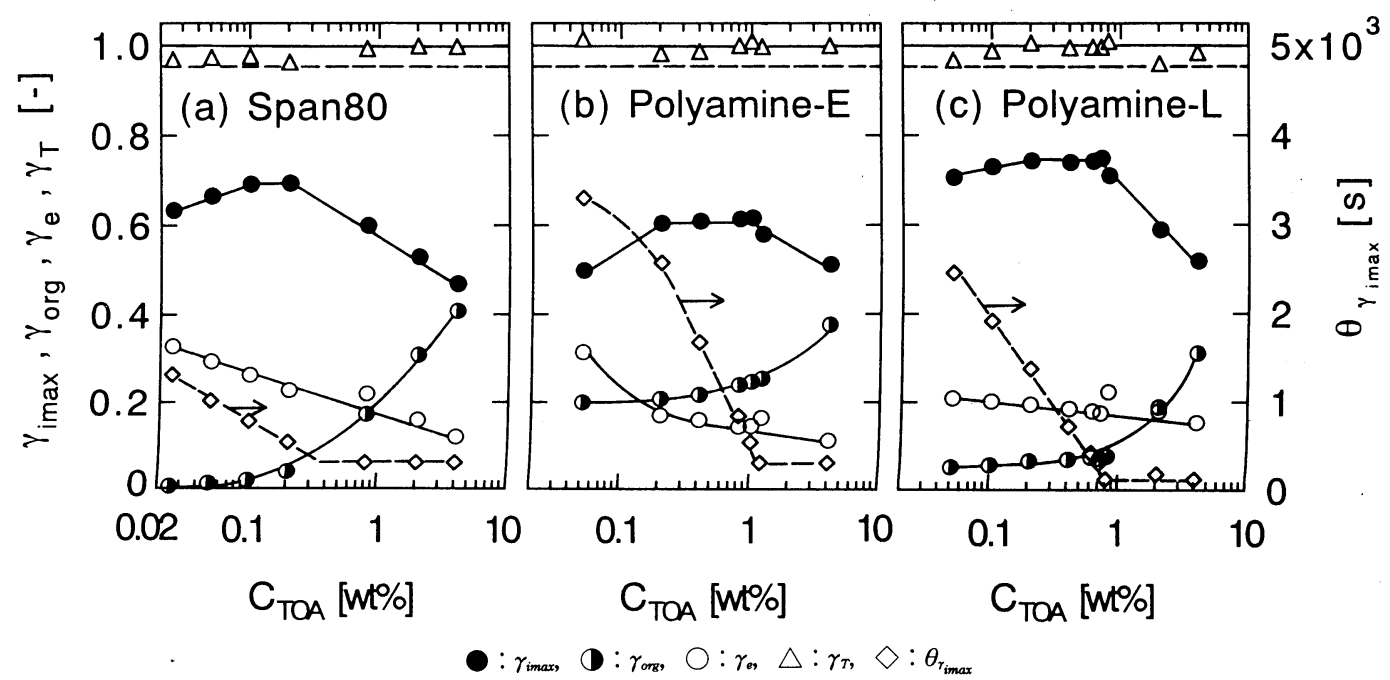

Fig. 1 Effects of $C_{T O A}$ on $\gamma_{\text {imas }} \gamma_{\text {ors }} \gamma_{e}$ and $\theta_{\gamma_{\text {imax }}}$

\section{実験方法}

実験装置および実験方法は，前報144 と同じである，界 面活性剂 Span $804 \mathrm{wt} \%$ （あるいはポリアミン $2 \mathrm{wt}$ \%）扔よび担体 TOA を含むケロシン油相溶液 $400 \mathrm{~cm}^{3}$ と $0.34 \mathrm{kmol} / \mathrm{m}^{3}$ の水酸化ナトリウム水溶液 $200 \mathrm{~cm}^{3}$ を 摫拌速度 $25 \mathrm{~s}^{-1}$ で 1200 秒間攪拌して, W/O エマル ションを調製した。酢酸・酢酸ナトリウムによって $\mathrm{pH}$ $=3.4$ にした重クロム酸カリウム水溶液（クロムイオン 濃度 $\left.3.85 \mathrm{~mol} / \mathrm{m}^{3}\right) \quad 700 \mathrm{~cm}^{3}$ に攪拌速度 $4.2 \mathrm{~s}^{-1}$ で攪拌し ながら W/O エマルション $100 \mathrm{~cm}^{3}$ を注入した。所定の 抽出時間後全量を 300 秒間静置し，W/O エマルション と外部水相を分離した. $\mathrm{W} / \mathrm{O}$ エマルションを 1200 秒 間電気解乳化 $(8 \mathrm{kV}, 1800 \mathrm{~Hz})$ し，油相と内部水相を 分離した．分離された外部水相，油相および内部水相の 体積およびクロムイオン濃度を測定した。

\section{実験結果および考察}

内部水相体積比 $V_{\mathfrak{V}} / V_{\boldsymbol{i}}^{0}$ の経時变化は, 本実験範囲内で は TOA 濃度の影響を受けず前報) と同様な経時変化を 示した．但し，Span 80 については時間 $\theta<2.4 \times 10^{3}$ 秒 である。

前報) の Fig. 3 と同様な外部水相, 油相, 内部水相中 のクロムイオン含有率 $\gamma_{e}, \gamma_{\text {orz }}, \gamma_{i}$ の経時变化を種々の TOA 濃度 $C_{T O A}$ について求めた. $\gamma_{i}$ の最大值 $\gamma_{\text {imax }}$ および $\gamma_{\text {imax }}$ に至る時間 $\theta_{r_{\text {imax }}}, \theta_{r_{\text {imax }}}$ における $\gamma_{e}, \gamma_{\text {org }}$ と $C_{T O A}$ の関 係を Fig. 1 に示した。 いづれの界面活性剤の場合も $\gamma_{e}$ は $C_{T O A}$ の増大と共に減少している. しかし， $\gamma_{\text {imax }}$ は $C_{T O A}$ の増加と共に増加し, ほぼ一定值に達し，その後 減少している。 $\gamma_{\text {imax }}$ の最大值はポリアミン-L $(0.75)>$
Span 80(0.7) >ポリアミン-E(0.62) の順番になってい る. $\gamma_{\text {imax }}$ の最大值をとる $C_{T O A}$ の範囲は, $\operatorname{Span} 80$ では $0.1 \sim 0.2 \mathrm{wt} \%$, ポリアミン-E では $0.2 \sim 1.0 \mathrm{wt} \%$, ポリアミン-L では $0.2 〜 0.7 \mathrm{wt} \%$ ある。.

$\theta_{r_{\text {imax }}}$ は $C_{\text {TOA }}$ の増大と共に減少している。したがって $\theta_{r_{\text {imax }}}$ における $V_{V} V_{i}^{0}$ は $C_{T O A}$ の増大と共に小さくなる. $V_{i} / V_{i}^{0}$ を小さくするため, 上記 $C_{T O A}$ 範囲内における大 きい $C_{T O A}$ （Span 80 では $0.2 \mathrm{wt} \% ，$ ポリアミン-Eでは $1.0 \mathrm{wt} \%$ ， ポリアミン-Lでは $0.7 \mathrm{wt} \%$ ） と，これに対 応する $\theta_{r_{\text {imax }}}$ の值 $\left(\operatorname{Span} 80\right.$ は $5.4 \times 10^{2}$ 秒，ポリアミン -Eは $5.4 \times 10^{2}$ 秒， ポリアミン $\mathrm{L}$ は $3 \times 10^{2}$ 秒） が最 適の操作条件である.

また, 最適操作条件の $C_{T O A}$ よりあ低濃度の領域では, $C_{T O A}$ の増大に伴う $\gamma_{e}$ の減少は $\gamma_{i \max }$ の増加に寄与してい る. すなわち, $C_{T O A}$ の増加は明らかに抽出能力を上げ ることを示している。 しかし， 最適 $C_{T O A}$ よりも高濃度 の領域では， $\gamma_{e}$ は引き続き減少し続けるが， $\gamma_{\text {imax }}$ は増加 せずに逆に隇少し， $\gamma_{\text {org }}$ が急激に増加している．このこ とは最適 $C_{T O A}$ 以上では, クロムイオンは内部水相中に 濃縮回収されずに，油相中に停滞していることを示して いる。 森ら ${ }^{3)}$ は高濃度の TOA（4 vol\%）において，油 相中に大部分が停滞していると推測したが，本実験の結 果はこれを支持している.

\section{Nomenclature}

$C_{T O A}=$ concentration of tri- $n$-octylamine $\quad[\mathrm{wt} \%]$

$V$ = volume

$\gamma=$ molar fraction of chromium 
$\theta \quad=$ time

$<$ Subscripts $>$

$e \quad=$ external phase

$i \quad=$ internal phase

$\max =$ maximum value

org =organic phase

$T=$ total

$<$ Superscript $>$

$0 \quad=$ initial value $[\mathrm{s}]$

\section{Literature cited}

1) Ando, K., S.Masaoka, T. Kohama, M. Akiyoshi and E. Obata : Kogyo Yosui, 339, 2-6 (1986)

2) Eguchi, W., Y.Mori, H. Uemae and S. Hibino : Kagaku Kogaku Symp. Ser., 12, $19-25$ (1987)

3) Mori, Y.,H. Uemae,S. Hibino and W. Eguchi : Kagaku Kogaku Ronbunshu, 13, 412-420 (1987)

4) Ye, W., E. Obata, and K. Ando: Kagaku Kogaku Ronbunshu, 20, $570-574$ (1994)

\title{
Extraction of Chromium with Liquid Surfactant Membranes Containing TOA Carrier \\ -Effect of TOA concentrations on chromium molar fractions \\ in the external, organic, internal phases-
}

\author{
Weiqing Ye, Shinichi Hara, Yuichi Ohira \\ Eiji Obata and Koji Ando
}

Dept. of Appl. Chem., Muroran Inst. of Tech., Muroran Hokkaido Japan 050

Key Words: Chromium, Extraction, Emulsion Liquid Membrane, Membrane Separation, Tri-n-octylamine

Experiments dealing with the effects of TOA concentrations on time courses of chromium molar fractions in the external, organic and internal phases during the separation-concentration process of chromium were carried out using Span 80 and two kinds of polyamine surfactants, Polyamine-E and Polyamine-L. The optimum TOA concentration and the optimum extraction time were determined in order to obtain the maximum chromium molar fraction in the internal phase. 